\title{
HIV Sero-Discordant Couples in Southwest Nigeria: Prevalence and Associated
} Risk Factors

\author{
Afe $\mathrm{AJ}^{* 1}$, Fadero $\mathrm{T}^{2}$ and Oluokun $\mathrm{O}^{3}$
}

${ }^{1}$ Community Medicine Department, Equitable Health Access Initiative, Lagos, Nigeria

${ }^{2} \mathrm{HIV}$ counselling and Testing unit, Community Medicine Department, Equitable Health Access Initiative, Lagos

Nigeria

${ }^{3}$ Clinical Department, Institute of Human Virology, Lagos, Nigeria

${ }^{*}$ Corresponding author: Afe AJ, Community Medicine Department, Equitable Health Access Initiative, P.O.Box 10047,G.P.O, Lagos, Nigeria, E-mail: abayomiafe@yahoo.com

Citation: Afe AJ, Fadero T, Oluokun O (2015) HIV Sero-discordant Couples in Southwest Nigeria:

Prevalence and Associated Risk Factors. J Aids Hiv Infec 1(1): 103. doi: 10.157444/2454-499X.1.103

Received Date: February 12, 2015 Accepted Date: April 01, 2015 Published Date: April 08, 2015

\begin{abstract}
This is a cross-sectional multicenter study to determine the prevalence of HIV sero- discordancy and the associated factors. A total of 166 respondents had questionnaire-based interview. All the respondents were PLHIV and most (87\%) have been in heterosexual relationship for at least one year. $13 \%(n=21)$ were male and $87 \%(n=145)$ were female and more than half of them $(57 \%)$ have been living with HIV for more than a year. Their modal CD4 count was $350-500 \mathrm{cell} / \mathrm{mm}^{3}$ and $93 \%$ of them were on ART. About $93 \%$ $(n=154)$ had no prior knowledge of their HIV status before starting the index sexual relationship, hence it is difficult to say if there were infected in the course of the present relationship. Opportunistic infection was present in $31 \%$ while $69 \%$ do not have any opportunistic infection. Co-infection with STI was present in $7 \%$ and almost $93 \%$ had no such infection. Up to $58 \%(\mathrm{n}=96)$ of the respondents have HIV negative partners (discordant couples), $40 \%(\mathrm{n}=66)$ have HIV positive partners (concordant partners) and $2 \%(\mathrm{n}=4)$ do not know their partners' HIV status. $96 \%$ of the study participants use contraceptive with condom being the commonest (95\%). But only half (56\%) have disclosed their sero-status to their partners. All the male partners are circumcised. Most partners (79\%) have repeated their HIV test to monitor their sero-status. The prevalence of sero-discordant couples calculated in this study is similar to what has been found in other African countries. Respondents with sero-discordant partners are more likely to have either primary $(18.75 \%$ vs $16.67 \%$ ) or tertiary ( $32.29 \%$ vs $22.73 \%$ ) education as the highest level of qualification, more likely to be in the age bracket $31-40 \mathrm{yrs}$ ( $43.75 \%$ vs $10.61 \%$ ), more likely to be unemployed ( 25 vs 19.7 ), more likely to know their own HIV status before starting the index relationship and less likely to disclose their HIV status to their partners (58.33\% vs $21.21 \%)$ while those with sero-concordant partners have more secondary education (60.0\% vs $48.96 \%$ ), more likely to have longer duration (date of HIV diagnosis) of HIV infection, more predisposed to opportunistic infections (46.96\% vs $19.79 \%$ ), more likely to have repeated HIV test for their sexual partners (98.48\% vs $68.75 \%$ ), more likely to have been in sexual relationship for 3years. No significant difference in the religious affiliations, use of ARV by the positive partners and condom use between the two groups. The hausa tribe has more sero-concordant relationship $(7.58 \%$ vs 3.1\%) while the other two major tribes (Yoruba and Igbo) have equal distribution of both sero-statuses. The low rate of status disclosure among partners is a cause for concern and may promote transmission, even though the rate of use of the prevention combination (ART,Condom and Circumcision) is high enough to mitigate such risks.
\end{abstract}

Keywords: HIV; Sero-discordant; Sero-concordant; ART; ARV; PLHIV; STI; CD4

Abbreviations: HIV: Human immune deficiency virus; ART: Antiretroviral therapy; ARV: Antiretroviral drugs; PLHIV: People living with HIV; STI: Sexually transmitted infection; CD4- CD4: T lymphocytes

\section{Introduction}

\section{Statement of the Problem}

Globally, an estimated 35.3 (32.2-38.8) million people were living with HIV in 2012. An increase from previous years as more people are receiving the life-saving antiretroviral therapy. There were 2.3 (1.9-2.7) million new HIV infections globally, showing a $33 \%$ decline in the number of new infections from $3.4(3.1-3.7)$ million in 2001. At the same time the number of AIDS deaths is also declining with 1.6 (1.4-1.9) million AIDS deaths in 2012, down from 2.3 (2.1-2.6) million in 2005 [1].

The Sub-saharan Africa accounts for a disproportionate burden of the global HIV epidemic. In 2013, the region had 25 million people living with HIV, 1.5 million new HIV infections and 1.1 million deaths due to HIV/AIDS [2]. The sub-saharan African region in 2013 also accounted for 6,000 new HIV infections daily, 2 out of every 3 new HIV infections in the world and 1 out of 3 such new infections were in the youths (15-24yrs) [3].

Nigeria with a population of 160million people has the second largest number of people living with human immunodeficiency virus (HIV) in the world after South Africa [3]. 
The national HIV prevalence in Nigeria was 3.4\% as at 2012 [4], the prevalence was higher among females (3.5\%) than males (3.3\%). This translated to about 2.95 million people (1.2 million men and 1.73 million women) living with the virus in the country. The number of new infections was put at 323,000 adults and 57,000 children. Infection rates among young people aged 15-19 was put at $3.3 \% ; 20-24 \mathrm{yr}$ old at $4.6 \%$ and $25-29$ years old at 5.6\% were considered very high [5].

The disparity in the population of male and female who are HIV infected as shown in the data above give rise to a phenomenon called HIV sero-discordancy defined as a situation in which one partner involved in a sexual relationship is HIV positive while the other partner is HIV negative. Other factors that give rise to HIV serodiscordant couples include higher risk of heterosexual HIV infection in female because of the larger surface area of the female sexual organ(the vagina) compared to the male, intergenerational sex and the risky medical procedures like childbirth. The vulnerability of the female gender make them a target of sexual violence like rape especially in crisis period. This coupled with the low economic power of most women in low income countries leading to engagement in sex for favor and lack of power to negotiate sex expose them to risky sex that can lead to HIV infection. Differential in age of first sexual encounter between male and female may also be a factor. Men on the other hand tend to engage in more extra-marital affair sexual intercourse, which often than not may be under the influence of substance or chemicals like drugs. By any of these means, a partner in sexual relationship may get infected with HIV either before starting the relationship or while still within an HIV negative concordant relationship thus converting such relationship into a serodiscordant type. Although one partner is currently HIV-negative, this does not mean that this partner is "immunized" or protected against getting HIV in the future. It is of paramount importance for sero-discordant couples to avoid transmission to the HIV-negative partner. It is possible for couples to stay HIV sero-discordant indefinitely if they consistently practice safer sex using male and female condoms. The annual risk of transmission of HIV from an infected partner to an uninfected partner in sero-discordant couples can be reduced from $20-25 \%$ to $3-7 \%$ in programmes where condom use is recommended for prevention [6].

The HIV-positive partner should receive care and treatment services for his or her own health. Treatment for the HIV-positive partner also is highly effective in reducing the risk of transmission to the HIV-negative partner. Combined, treatment and consistent condom use are likely to offer greater protection than either one alone. The couple also should receive information about family planning. For sero-discordant couples who are having unprotected sex or who desire children, the use of ART to make conception safer (both to keep the partner negative and protect the child from HIV infection) is an important benefit.

Sero-discordant couples who are aware of each other's HIV status may be able to support access and adherence to treatment, to give each other emotional support, and to support uptake of and adherence to PMTCT interventions. In most sub-Saharan African countries with generalized HIV epidemics, three-quarters of adults ages 20-49 years report being in cohabiting relationships [79]. Among people with HIV who are in stable relationships, up to half have an HIV-negative partner-that is, they are in a serodiscordant relationship (one partner is HIV-positive, the other is HIV-negative) [4]. Such proportions have been reported in both the general population [10-12] and specifically among women and their partners attending antenatal clinics [13-15].

\section{Literature Review}

In most studies of sero-discordant relationships, half of the infected partners are male and half are female. Data from 27 cohorts totaling 13, 061 sero-discordant couples in sub-Saharan Africa and Demographic and Health Survey (DHS) data on 1,145 serodiscordant couples in 14 countries indicated that the proportion of HIV-positive women in stable heterosexual sero-discordant relationships was 47\% [7]. Population surveys in 2007-2008 in low- and middle-income countries revealed thatknowledge of HIV status is still low among people with HIV, with a median of $40 \%$ in 10 countries [13]. Furthermore, the majority of men and women in relationships are unaware of their partner's status, and many people with an HIV-positive partner are not aware of their own status, leaving many people unknowingly vulnerable to HIV infection [8,14]. Several studies also have found that, when serodiscordant partners are unaware of each other's status and HIV transmission occurs, it is frequently between partners [15-18]. The fact that transmission from one partner to another accounts for a high percentage of HIV transmission within stable partnerships is confirmed by a study in Zambia, in which DNA sequencing revealed that $87 \%$ of new HIV infections in the negative partner in a sero-discordant relationship were acquired from the HIV-positive partner [19]. Another study, conducted at 14 sites in southern and eastern Africa, found that $64 \%$ of seroconversions could be linked by viral sequencing to the HIV-positive partner in a longterm relationship [20].

Possible explanations for discordancy that have been put forward by other researchers include the concept of a hidden infection not detectable by HIV tests, belief in immunity, the thought that gentle sex protected HIV negative partners, and belief in protection by God [21].

Despite growing evidence of its importance, the concept of "sero-discordance" and the frequency of its occurrence are poorly understood in most communities [22,23]. Often, policymakers and health workers, too, are unaware of its high frequency and importance, resulting in insufficient emphasis on necessary treatment strategies that can protect the negative partner and improve the life of positive client. 92\% reduction in HIV-1 transmission risk in sero-discordant couples with HIV-infected partner receiving antiretroviral therapy relative to couples with infected partner not receiving antiretroviral treatment has been demonstrated in studies like the Sub analysis of Partners in Prevention HSV/HIV Transmission Study [24]. 
HIV prevention with sero-discordant couples is a relatively new area of prevention program in many developing countries. Only a small number of current interventions are targeted at this group. Challenges and barriers associated with such HIV prevention activities include difficulty in getting partners to participate in an HIV service uptake, gender inequality and misconceptions about sero-discordancy. HIV prevention strategies that have been shown to be effective with HIV sero-discordant couples include Couples HIV Counseling and Testing (CHCT), group-based interventions that focus on the provision of information, developing risk reduction strategies, and developing personal skills. Others include provision of supportive environment to reduce stigma and overcome barriers posed by finance and logistics to accessing care. Cultural attitudes and beliefs may also need to change, for example for CHCT to be effective within antenatal clinical settings, the perception that antenatal care is only for women needs to be addressed.

\section{Justification}

No similar local study on the prevalence of HIV sero-discordance in this setting. It is also to raise awareness on HIV serodiscordant couples. As Nigeria, prepares to adopt the 2013 WHO consolidated guideline on the use of antiretroviral drugs for HIV treatment and prevention which specifies sero-discordant relationship as an indication for ARV initiation, it is important to have this type of study to estimate the prevalence of sero-discordancy in our setting and thus the percentage of clients that may have to be initiated on ARV based on this indication.

\section{Research Question}

What is the prevalence of HIV sero-discordance in southwest Nigeria and factors associated with HIV sero-discordancy?

\section{Objectives}

To determine the Prevalence of HIV sero-discordant couples in southwest Nigeria. To knowFactors Associated with HIV serodiscordant couples in southwest Nigeria.

\section{Methodology}

Study Area: Thirteen public hospitals in Ondo and Ekiti states in southwest Nigeria which offer HIV care and treatment services. The study was conducted in the ART clinics of these hospitals.

Study Design: This is a cross-sectional questionnaire-based study.

Study Population: HIV positive clients accessing care and treatment at the study centers.

Study Period: August 2013 to August 2014.

Sample Size: The minimum sample size of 150 participants is required for sample proportion with $2.5 \%$ margin of error and 95\% level of confidence calculated using Fisher's formula. But with a 10\% mark, this figure becomes 166 so as to cover for losses through improperly filled or lost questionaires. The study participants were recruited from the ART clinics at 13 Public hospitals in Ondo and Ekiti states in southwest Nigeria which offer HIV care and treatment services on the support from PEPFAR programme.

Sampling Method: Non probability sampling method used to give out 166 questionnaires.

\section{Inclusion criteria:}

1) People living with HIV (PLHIV)

2) Ongoing sexual relationship

3) Accessing HIV care and treatment at the study sites

4) Informed consent to participate

Ethical consideration: Consent was obtained from the respondents after giving them detailed explanation of what the study entailed. Only those who agreed to participate had the questionaires administered on them.

Data Collection: Questionaires were designed for this study, and this was tested for validity and reliability using expert opinion and pre-testing with potential study participants before they were finally administered by the interviewers. After the interview, they were checked for completeness before entry into a data-base. Only those with complete information were used.

Data Analysis: The data was subsequently imported into SPSS for analysis.

\begin{tabular}{|c|c|c|c|}
\hline \multicolumn{2}{|c|}{ VARIABLES } & FREQUENCY (n=162) & \% FREQUENCY \\
\hline \multirow{2}{*}{ AGE } & less than 20yrs & 24 & 14.81 \\
\cline { 2 - 4 } & $20-30 \mathrm{yrs}$ & 84 & 51.85 \\
\cline { 2 - 4 } & $31-40 \mathrm{yrs}$ & 49 & 30.25 \\
\cline { 2 - 4 } & $41-50 \mathrm{yrs}$ & 5 & 3.09 \\
\hline \multirow{2}{*}{ GENDER } & & 22 & 0.00 \\
\cline { 2 - 4 } & Male & 140 & 86.42 \\
\hline
\end{tabular}




\begin{tabular}{|c|c|c|c|}
\hline \multicolumn{2}{|c|}{ VARIABLES } & \multirow[t]{2}{*}{ FREQUENCY $(n=162)$} & \multirow{2}{*}{$\begin{array}{c}\text { \% FREQUENCY } \\
0.00\end{array}$} \\
\hline EDUCATIONAL LEVEL & & & \\
\hline & None & 0 & 0.00 \\
\hline & Primary & 29 & 17.90 \\
\hline & Secondary & 87 & 53.70 \\
\hline & Tertiary & 46 & 28.40 \\
\hline \multirow{4}{*}{ TRIBE } & & & 0.00 \\
\hline & Yoruba & 121 & 74.69 \\
\hline & Hausa & 8 & 4.94 \\
\hline & Igbo & 33 & 20.37 \\
\hline \multirow[t]{3}{*}{ RELIGION } & & & 0.00 \\
\hline & Christianity & 148 & 91.36 \\
\hline & Islam & 14 & 8.64 \\
\hline \multirow[t]{4}{*}{ OCCUPATION } & & & 0.00 \\
\hline & Trading/Business & 89 & 54.94 \\
\hline & Artesian/Profession & 36 & 22.22 \\
\hline & Unemployed & 37 & 22.84 \\
\hline \multirow[t]{9}{*}{ YEAR OF INFECTION } & & & 0.00 \\
\hline & 2006 & 2 & 1.23 \\
\hline & 2007 & 2 & 1.23 \\
\hline & 2008 & 4 & 2.47 \\
\hline & 2009 & 14 & 8.64 \\
\hline & 2010 & 22 & 13.58 \\
\hline & 2011 & 19 & 11.73 \\
\hline & 2012 & 28 & 17.28 \\
\hline & 2013 & 71 & 43.83 \\
\hline \multirow[t]{3}{*}{ PRIOR KNOWLEDGE OF STATUS } & & & 0.00 \\
\hline & Yes & 11 & 6.79 \\
\hline & No & 151 & 93.21 \\
\hline \multirow[t]{8}{*}{ CD4 } & & & 0.00 \\
\hline & Less than 200 & 28 & 17.28 \\
\hline & 201-350 & 34 & 20.99 \\
\hline & $351-500$ & 34 & 20.99 \\
\hline & $501-700$ & 23 & 14.20 \\
\hline & $701-900$ & 16 & 9.88 \\
\hline & 901-1101 & 9 & 5.56 \\
\hline & 1102 and Above & 4 & 2.47 \\
\hline
\end{tabular}

Table 1: Demographics

\begin{tabular}{|c|c|c|c|}
\hline \multicolumn{2}{|c|}{ VARIABLES } & FREQUENCY (n=162) & \% FREQUENCY \\
\hline \multirow{3}{*}{ HIV STATUS OF SEXUAL PARTNERS } & POSITIVE(CONCORDANT) & 66 & 40.74 \\
\cline { 2 - 4 } & NEGATIVE(DISCORDANT) & 96 & 59.26 \\
\hline \multirow{3}{*}{ TYPE ARV DRUG REGIMEN } & & & 0.00 \\
\cline { 2 - 4 } & AZT/3TC/NVP & 89 & 54.94 \\
\cline { 2 - 4 } & AZT/3TC/EFV & 39 & 24.07 \\
\cline { 2 - 4 } & TDF/FTC/NVP & 4 & 2.47 \\
\cline { 2 - 4 } & TDF/FTC/EFV & 8 & 4.94 \\
\cline { 2 - 4 } & TDF/3TC/NVP & 2 & 1.23 \\
\cline { 2 - 4 } & TDF/3TC/EFV & 1 & 0.62 \\
\cline { 2 - 4 } & Others & 19 & 11.73 \\
\hline
\end{tabular}




\begin{tabular}{|c|c|c|c|}
\hline \multicolumn{2}{|c|}{ VARIABLES } & \multirow[t]{2}{*}{ FREQUENCY $(\mathrm{n}=162)$} & \multirow{2}{*}{$\begin{array}{c}\text { \% FREQUENCY } \\
0.00\end{array}$} \\
\hline USE OF ARV & & & \\
\hline & Yes & 151 & 93.21 \\
\hline & No & 11 & 6.79 \\
\hline \multirow[t]{3}{*}{ OPPORTUNISTIC INFECTIONS } & & & 0.00 \\
\hline & Yes & 50 & 30.86 \\
\hline & No & 112 & 69.14 \\
\hline \multirow[t]{3}{*}{ REPEAT PARTNER HIV TEST } & & & 0.00 \\
\hline & Yes & 131 & 80.86 \\
\hline & No & 31 & 19.14 \\
\hline \multirow[t]{3}{*}{ TYPE OF SEXUAL RELATIONSHIP } & & & 0.00 \\
\hline & Heterosexual & 162 & 100.00 \\
\hline & Homosexual & 0 & 0.00 \\
\hline \multirow{3}{*}{$\begin{array}{l}\text { PARTNERS KNOWDGEMENT OF } \\
\text { STATUS(DISCLOSURE) }\end{array}$} & & & 0.00 \\
\hline & Yes & 92 & 56.79 \\
\hline & No & 70 & 43.21 \\
\hline \multirow{8}{*}{$\begin{array}{l}\text { DURATION OF SEXUAL RELATION- } \\
\text { SHIP }\end{array}$} & & & 0.00 \\
\hline & Less than $2 y r s$ & 12 & 7.41 \\
\hline & $2 \mathrm{yrs}$ & 42 & 25.93 \\
\hline & $3 \mathrm{yrs}$ & 39 & 24.07 \\
\hline & 4yrs & 29 & 17.90 \\
\hline & $5 y r s$ & 15 & 9.26 \\
\hline & 6yrs & 8 & 4.94 \\
\hline & 7yrs and above & 12 & 7.41 \\
\hline \multirow[t]{5}{*}{ TYPES OF CONTRACEPTIVE } & & & 0.00 \\
\hline & PILL & 1 & 0.62 \\
\hline & CONDOM & 154 & 95.06 \\
\hline & INJECTABLES & 1 & 0.62 \\
\hline & NONE & 6 & 3.70 \\
\hline \multirow[t]{3}{*}{ MALE PARTNER CIRCUMCISED } & & & 0.00 \\
\hline & Yes & 162 & 100.00 \\
\hline & No & 0 & 0.00 \\
\hline
\end{tabular}

Table 2: Demographics

\begin{tabular}{|c|c|c|c|c|}
\hline VARIABLES & TOTAL $(n=162)$ & $\begin{array}{c}\text { Seroconcordant } \\
\quad(n=66) \%\end{array}$ & $\begin{array}{c}\text { Serodiscordant } \\
\quad(n=96) \%\end{array}$ & $\begin{array}{r}\text { P value,Odds } \\
\text { Ratio(OR),CHI } \\
\text { Square,CI }\end{array}$ \\
\hline \multicolumn{5}{|l|}{ AGE } \\
\hline less than $20 y r s$ & 24 & 34.84 & 1.04 & \\
\hline $20-30 y r s$ & 84 & 53.03 & 51.04 & \\
\hline $31-40 y r s$ & 49 & 10.61 & 43.75 & \\
\hline 41-50yrs & 5 & 1.52 & 4.17 & \\
\hline GENDER & & & & $\begin{array}{r}\text { pvalue }=0.00 ; \\
\text { OR=6.314; } \\
\text { CI }=(2.197,18.151) \\
\text { CHI Square }=14.07\end{array}$ \\
\hline$\%$ Male & 22 & 25.76 & 5.21 & \\
\hline$\%$ Female & 140 & 74.24 & 94.79 & \\
\hline \multicolumn{5}{|l|}{$\begin{array}{l}\text { EDUCATIONAL } \\
\text { LEVEL }\end{array}$} \\
\hline$\%$ None & 0 & 0 & 0 & \\
\hline$\%$ Primary & 29 & 16.67 & 18.75 & \\
\hline
\end{tabular}




\begin{tabular}{|c|c|c|c|c|}
\hline VARIABLES & TOTAL $(n=162)$ & $\begin{array}{l}\text { Seroconcordant } \\
\quad(n=66) \%\end{array}$ & $\begin{array}{l}\text { Serodiscordant } \\
\quad(n=96) \%\end{array}$ & $\begin{array}{r}\text { P value, Odds } \\
\text { Ratio(OR),CHI } \\
\text { Square,CI }\end{array}$ \\
\hline \%Secondary & 87 & 60.6 & 48.96 & \\
\hline$\%$ Tertiary & 46 & 22.73 & 32.29 & \\
\hline \multicolumn{5}{|l|}{ TRIBE } \\
\hline$\%$ Yoruba & 121 & 72.73 & 76.04 & \\
\hline$\%$ Hausa & 8 & 7.58 & 3.13 & \\
\hline \% Igbo & 33 & 19.7 & 20.83 & \\
\hline RELIGION & & & & $\begin{array}{r}\text { pvalue }=0.866 ; \\
\mathrm{OR}=0.909 ; \\
\mathrm{CI}=(0.3,2.754) \mathrm{CHI} \\
\text { Square }=0.028\end{array}$ \\
\hline \% Christianity & 148 & 90.91 & 91.67 & \\
\hline \% Islam & 14 & 9.09 & 8.33 & \\
\hline OCCUPATION & & & & $\begin{array}{r}\text { p-value }=0.643 ; \\
\text { CHI Square }=0.882\end{array}$ \\
\hline$\%$ Trading/Business & 89 & 59.09 & 52.08 & \\
\hline$\%$ Artesian/Profession & 36 & 21.21 & 22.92 & \\
\hline \% Unemployed & 37 & 19.7 & 25 & \\
\hline \multicolumn{5}{|l|}{$\begin{array}{l}\text { YEAR OF INFEC- } \\
\text { TION }\end{array}$} \\
\hline 2006 & 2 & 1.52 & 1.04 & \\
\hline 2007 & 2 & 0 & 2.08 & \\
\hline 2008 & 4 & 3.03 & 2.08 & \\
\hline 2009 & 14 & 12.12 & 6.25 & \\
\hline 2010 & 22 & 16.67 & 11.46 & \\
\hline 2011 & 19 & 18.18 & 7.29 & \\
\hline 2012 & 28 & 18.18 & 16.67 & \\
\hline 2013 & 71 & 30.3 & 53.13 & \\
\hline $\begin{array}{l}\text { PRIOR KNOWLEDGE } \\
\text { OF HIV STATUS }\end{array}$ & & & & $\begin{array}{r}\text { pvalue }=0.029 ; \\
\text { OR }=0.132 ; \mathrm{CI} \\
=(0.017,1.060) ; \\
\text { CHI Square }=4.897\end{array}$ \\
\hline$\%$ Yes & 11 & 1.52 & 10.42 & \\
\hline$\%$ No & 151 & 98.48 & 89.58 & \\
\hline \multicolumn{5}{|l|}{ CD4 COUNT } \\
\hline \% Less than 200 & 28 & 19.7 & 15.63 & \\
\hline$\%$ 201-350 & 34 & 19.7 & 21.88 & \\
\hline$\% 351-500$ & 34 & 25.76 & 17.71 & \\
\hline$\% 501-700$ & 23 & 10.61 & 16.67 & \\
\hline$\% 701-900$ & 16 & 13.64 & 7.29 & \\
\hline$\%$ 901-1101 & 9 & 1.52 & 8.33 & \\
\hline$\% 1102$ and Above & 4 & 1.52 & 3.13 & \\
\hline
\end{tabular}

Table 3: Seroconcordants Vs Serodiscordant

\begin{tabular}{|c|c|c|c|c|}
\hline $\begin{array}{r}\text { TYPE ARV DRUG } \\
\text { REGIMEN }\end{array}$ & TOTAL $(\mathbf{n = 1 6 2 )}$ & $\begin{array}{c}\text { Seroconcordant } \\
(\mathbf{n = 6 6 )} \%\end{array}$ & $\begin{array}{c}\text { Serodiscordant } \\
(\mathbf{n = 9 6}) \%\end{array}$ & $\begin{array}{r}\text { Pvalue,Odds } \\
\text { Ratio(OR),CI,CHI } \\
\text { Square, }\end{array}$ \\
\hline$\% \mathrm{AZT} / 3 \mathrm{TC} / \mathrm{NVP}$ & 89 & 53.03 & 56.25 & \\
\hline$\% \mathrm{AZT} / 3 \mathrm{TC} / \mathrm{EFV}$ & 39 & 21.21 & 26.04 & \\
\hline$\% \mathrm{TDF} / \mathrm{FTC} / \mathrm{NVP}$ & 4 & 6.06 & 0 & \\
\hline$\% \mathrm{TDF} / \mathrm{FTC} / \mathrm{EFV}$ & 8 & 7.58 & 3.13 & \\
\hline$\% \mathrm{TDF} / 3 \mathrm{TC} / \mathrm{NVP}$ & 2 & 0 & 2.08 & \\
\hline$\% \mathrm{TDF} / 3 \mathrm{TC} / \mathrm{EFV}$ & 1 & 1.52 & 0 & \\
\hline$\% \mathrm{Others}$ & 19 & 10.61 & 12.5 & \\
\hline
\end{tabular}




\begin{tabular}{|c|c|c|c|c|}
\hline TYPE ARV DRUG REGIMEN & TOTAL $(n=162)$ & $\begin{array}{l}\text { Seroconcordant } \\
\quad(\mathbf{n}=66) \%\end{array}$ & $\begin{array}{l}\text { Serodiscordant } \\
\quad(\mathbf{n}=96) \%\end{array}$ & $\begin{array}{c}\text { Pvalue,Odds } \\
\text { Ratio(OR),CI,CHI } \\
\text { Square, }\end{array}$ \\
\hline USE OF ARV & & & & $\begin{array}{c}\text { pvalue }=0.742 ; \\
\text { OR }=0.813 ; \mathrm{CI} \\
=(0.238,2.784) ; \\
\text { CHISquare }=0.109\end{array}$ \\
\hline$\%$ Yes & 151 & 92.42 & 93.75 & \\
\hline$\%$ No & 11 & 7.58 & 6.25 & \\
\hline $\begin{array}{l}\text { OPPORTUNISTIC INFEC- } \\
\text { TION }\end{array}$ & & & & $\begin{array}{c}\text { Pvalue }=0.742 ; \\
\mathrm{OR}=0.813 ; \mathrm{CI} \\
=(0.238,2.784) ; \\
\text { CHISquare }=0.109\end{array}$ \\
\hline$\%$ Yes & 50 & 46.97 & 19.79 & \\
\hline$\%$ No & 112 & 53.03 & 80.21 & \\
\hline REPEAT PARTNER HIV TEST & & & & $\begin{array}{c}\text { p-value }=0.00 ; \\
\text { OR=29.55; CI } \\
=(3.913,223.09) ; \\
\text { CHI Square }=22.35\end{array}$ \\
\hline$\%$ Yes & 131 & 98.48 & 68.75 & \\
\hline$\%$ No & 31 & 1.52 & 31.25 & \\
\hline \multicolumn{5}{|l|}{$\begin{array}{c}\text { TYPE OF SEXUAL RELA- } \\
\text { TIONSHIP }\end{array}$} \\
\hline$\%$ Heterosexual & 162 & 100 & 100 & \\
\hline$\%$ Homosexual & 0 & 0 & & \\
\hline $\begin{array}{l}\text { PARTNERS KNOWDGEMENT } \\
\text { OF STATUS(DISCLOSURE) }\end{array}$ & & & & $\begin{array}{c}\mathrm{p} \text {-value }=0.00 ; \\
\mathrm{OR}=5.2 ; \mathrm{CI} \\
=(2.541,10.642) \\
\text { CHI Square }=21.96\end{array}$ \\
\hline$\%$ Yes & 92 & 78.79 & 41.67 & \\
\hline$\%$ No & 70 & 21.21 & 58.33 & \\
\hline \multicolumn{5}{|l|}{$\begin{array}{l}\text { DURATION OF SEXUAL } \\
\text { RELATIONSHIP }\end{array}$} \\
\hline$\%$ Less than $2 \mathrm{yrs}$ & 12 & 1.52 & 11.46 & \\
\hline$\% 2 \mathrm{yrs}$ & 42 & 9.09 & 37.5 & \\
\hline$\% 3 y r s$ & 39 & 36.36 & 15.63 & \\
\hline$\% 4$ yrs & 29 & 22.73 & 14.58 & \\
\hline$\% 5 y r s$ & 15 & 9.09 & 9.38 & \\
\hline$\% 6$ yrs & 8 & 6.06 & 4.17 & \\
\hline 7yrs and above & 12 & 13.64 & 3.13 & \\
\hline \multicolumn{5}{|l|}{ TYPES OF CONTRACEPTIVE } \\
\hline$\%$ PILL & 1 & 0 & 1.04 & \\
\hline$\%$ CONDOM & 154 & 95.45 & 94.79 & \\
\hline \% INJECTABLES & 1 & 1.52 & 0 & \\
\hline$\%$ NONE & 6 & 3.03 & 4.17 & \\
\hline \multicolumn{5}{|l|}{$\begin{array}{l}\text { MALE PARTNER CIRCUM- } \\
\text { CISED }\end{array}$} \\
\hline$\%$ Yes & 162 & 100 & 100 & \\
\hline$\%$ No & 0 & 0 & 0 & \\
\hline
\end{tabular}

Table 4: Seroconcordants Vs Serodiscordant

\section{Results}

Of the 166 questionaires given out, only 162 were retrieved and analysed representing $98 \%$ response rate. $86 \%$ of the respondents were female while $14 \%$ were male. They were all HIV positive with more than half of them (57\%) diagnosed more than a year ago. Only 7\% knew their HIV status prior to starting the index relationship and the remaining 93\% only got to know their HIV status during the relationship. So, it is difficult to say if the majority of respondents were infected prior to or in the course of the relationship. They were all involved in an ongoing sexual relationship. Half of them had secondary level of education and are self- 
employed in business. 93\% of them were on antiretroviral therapy with AZT/3TC/NVP being the commonest first-line regimen; a proven preventive tool against HIV transmission. Over 70\% had a CD4 count (baseline or repeat) of less than or equal to 500700 cells $/ \mathrm{mm}^{3}$ and this accounts for the large number placed on ART; CD4 count of $\leq 350-500$ cells $/ \mathrm{mm}^{3}$ being a threshold for initiating ARV in this setting (Table 3). Only 31\% of the respondents have had opportunistic infections. 59\% had sero-discordant partners and $41 \%$ had sero-concordant partners. They all practice heterosexual intercourse and $95 \%$ use condom as contraceptive, though the correct and consistent use of this was not assessed. All the male partners are circumcised; another protective factor against HIV sexual transmission. Only $56 \%$ of the respondents have disclosed their HIV status to their sexual partners and most (75\%) have been in relationship for between one and 5years. $80 \%$ of the sexual partners have repeated their HIV test to monitor their sero-status. More males (25.76:p-value $=0.00 ; \mathrm{OR}=6.314)$ are more likely to have a seroconcordant partners while females (94.79 vs 74.24) have more sero-discordant partners compared to their male counterparts. More respondents within the age bracket $31-40 y r s(43.75 \%$ vs $10.61 \%)$ are likely to have discordants partners while those less than $20 y$ rs are more likely to have concordant partners. Respondents with sero-discordant partners are more likely to have either primary (18.75\% vs 16.67\%) or tertiary ( $32.29 \%$ vs $22.73 \%$ ) education as the highest level of qualification, more likely to be unemployed (25 vs 19.7 ), more likely to know their own HIV status before starting the index relationship while those with seroconcordant partners have more secondary education (60.0\% vs $48.96 \%$ ), more likely to have longer duration (date of HIV diagnosis) of HIV infection, more predisposed to opportunistic infections (46.96\% vs $19.79 \%$ ), more likely to have repeated HIV test for their sexual partners. More subjects in concordant relationship are likely to have disclosed their HIV status to their partners $(78.79 \%$ vs $41.67 \%)$ while the rate of disclosure among the sero-discordantis lower (58.33\% vs $21.21 \%)$. They are also more likely to have been in sexual relationship for 3years or longer while the serodiscordant couples relationship has lasted for shorter period. No significant difference in the religious affiliations, use of ARV by the positive partners and condom use between the two groups (Table 4). The hausa tribe $(7.58 \%$ vs 3.1$) 3 \%$ has more sero-concordant relationship while the other two major tribes (Yoruba and Igbo) have equal distribution of both sero-status.

\section{Discussion}

The low level of disclosure among the respondents is a course for concern as this may promote HIV transmission. However, the high prevalence of the use of the prevention combination (ART-93\%, Condom-95\%, Male Circumcision-100\%) among the respondents and their partners could have contributed in keeping the transmission level at $41 \%$ HIV sero-concordancy. Data from other African countries shows that two-thirds of infected couples are discordant in Burkina Faso, Cameroon, Ghana, Kenya, and Tanzania; between 30 and 40 percent of the infected couples are discordant couples where the female partner only is infected (dispelling a common perception that it is solely men who are putting their female partner at risk) [10]. Across east Africa, national representative data suggest 40 to 50 percent of married HIV infected individuals have an HIV uninfected spouse [25].

\section{Conclusion}

Like many other studies in Sub-saharan Africa, the prevalence rate of HIV sero-discordancy of 59\% calculated in this study is not too different from other findings. Because practices like ARV use and condom use are prevalent among the respondents, it is not surprising that this prevalent rate is found in this study. However, rate of disclosure of sero-status to sexual partners is low at average and may actually pose a risk to the sexual partners. Status disclosure especially by HIV positive clients needs to be promoted. HIV testing and counseling (HTC) before commencement of sexual relationship and during an ongoing relationship should be promoted as an important step in identifying and managing HIV sero-status of couples.

\section{Acknowledgement}

1) IHVN ACTIONPLUS-Up project 2) EHAI ACTIONPLUS-Up project 3) Miss BisoyeKalejaye, EHAIAkure

\section{References}

1.UNAIDS (2013) Report on the global AIDS epidemic.

2. UNAIDS (2013) Global Report 2014 \& Kaiser Foundation Report.

3. UNAIDS (2014) Global Report.

4. National HIV\&AIDS and Reproductive Health Surve (NARHS Plus II, 2012) Federal Ministry of Health, Abuja, Nigeria.

5. Federal Ministry of Health (2008) National HIV \& AIDS and Reproductive Health Survey, 2007 (NARHS Plus), Federal Ministry of Health Abuja, Nigeria.

6. DunkleKL, Stephenson R, Karita E, Chomba E, KayitenkoreK, et al. (2008) New heterosexually transmitted HIV infections in married or cohabiting couples in urban Zambia and Rwanda: an analysis of survey and clinical data. The Lancet 371: 2183-91.

7. Eyawo O, de Walque D, Ford N, Gakii G, Lester RT, et al. (2011) HIV status in discordant couples in sub-Saharan Africa: a systematic review and meta-analysis. Lancet Infect Dis 11: 263-4.

8. LingappaJR, Lambdin B, Bukusi EA, Ngure K, KavumaL, et al. (2008) Regional differences in prevalence of HIV-1 discordance in Africa and enrollment of HIV-1 discordant couples into an HIV-1 prevention trial. PLoS One 3: e1411.3.

9. Demographic and Health Survey (DHS) 2000-2010.

10. 5 De Walque D (2007) Sero-discordant couples in five African countries: Implications for prevention strategies. Population and Development Review 33: 501-23. 
11. KAIS (2007) Collaborating Institutions. Kenya AIDS Indicator Survey (KAIS) 2007. Final report, September 2009.

12. Lurie MN, Williams BG, Zuma K, Mkaya-Mwamburi D, Garnett GP, et al. (2003) Who infects whom? HIV-1 concordance and discordance among migrant and non-migrant couples in South Africa. AIDS 17: 2245-52.

13. Sagay AS, Onakewhor J, Galadanci H, Emuveyan EE (2006) HIV status of partners of HIV positive pregnant women in different regions of Nigeria: matters arising. African J Medicine Medical Sci 35: 125-9.

14. Msuya SE, Mbizvo EM, Hussain A, Uriyo J, Sam NE, et al. (2008) Low male partner participation in antenatal HIV counselling and testing in northern Tanzania: implications for preventive programs. AIDS Care 20: 700-9.

15. Farquhar C, Kiarie JN, Richardson BA, Kabura MN, John FN, et al. (2004) Antenatal couple counseling increases uptake of interventions to prevent HIV-1 transmission. J Acquir Immune Defic Syndr 37:1620-6.

16. Hugonnet S, Mosha F, Todd J, Mugeye K, Klokke A, et al. (2002) Incidence of HIV infection in stable sexual partnerships: a retrospective cohort study of 1802 couples in Mwanza Region, Tanzania. J Acquir Immune Defic Syndr 30: 73-80.

17. Malamba SS, Mermin JH, Bunnell R, Mubangizi J, Kalule J, et al. (2005) Couples at risk: HIV-1 concordance and discordance among sexual partners receiving voluntary counseling and testing in Uganda. J Acquir Immune Defic Syndr 39: 576-80.

18. Kaiser R, Bunnell R, Hightower A, Kim AA, Cherutich P, et al. (2011) Factors associated with HIV infection in married or cohabitating couples in Kenya: Results from a nationally representative study. PLoS One 6: e178421.

19. Allen S, Meinzen-Derr J, Kautzman M, Zulu I, Trask S, et al. (2003) Sexual behavior of HIV discordant couples after HIV counseling and testing. AIDS 17: 733-40.

20. Celum C, Wald A, Lingappa JR, Magaret AS, Wang RS, et al. (2010) Acyclovir and transmission of HIV-1 from persons infected with HIV-1 and HSV-2. New England J Med 362: 427-38.

21. MamanS, Mbwambo JK, Hogan NM, Kilonzo GP, Campbell JC, et al. (2002) HIV-positive Women Report More Lifetime Partner Violence: Findings from a Voluntary Counseling and Testing Clinic in Dar es Salaam, Tanzania. Am J Public Health 92: 1331-37.

22. Were E, Wools-Kaloustian K, Baliddawa J, Ayuo PO, Sidle J, et al. (2008) Stakeholders perception of HIV sero-discordant couples in western Kenya. East African Medical Journal 85: 326-33.

23. Kelley AL, Karita E, Sullivan PS, Katangulia F, Chomba E, et al. (2011) Knowledge and perceptions of couples' voluntary counseling and testing in urban Rwanda and Zambia: a cross-sectional household survey. PLoS ONE 6: e19573.

24. Donnell D, Kiarie J, Thomas K, J Baeten, J Lingappa, et al. (2010) ART and risk of heterosexual HIV-1 transmission in HIV-1 serodiscordant African couples: a multinational prospective study. Program and abstracts of the $17^{\text {th }}$ Conference on Retroviruses and Opportunistic Infections February $16-9$.

25. Bunnell R, Cherutich P(2008) Universal HIV Testing and Counselling in Africa. Lancet 371: 2148-50.

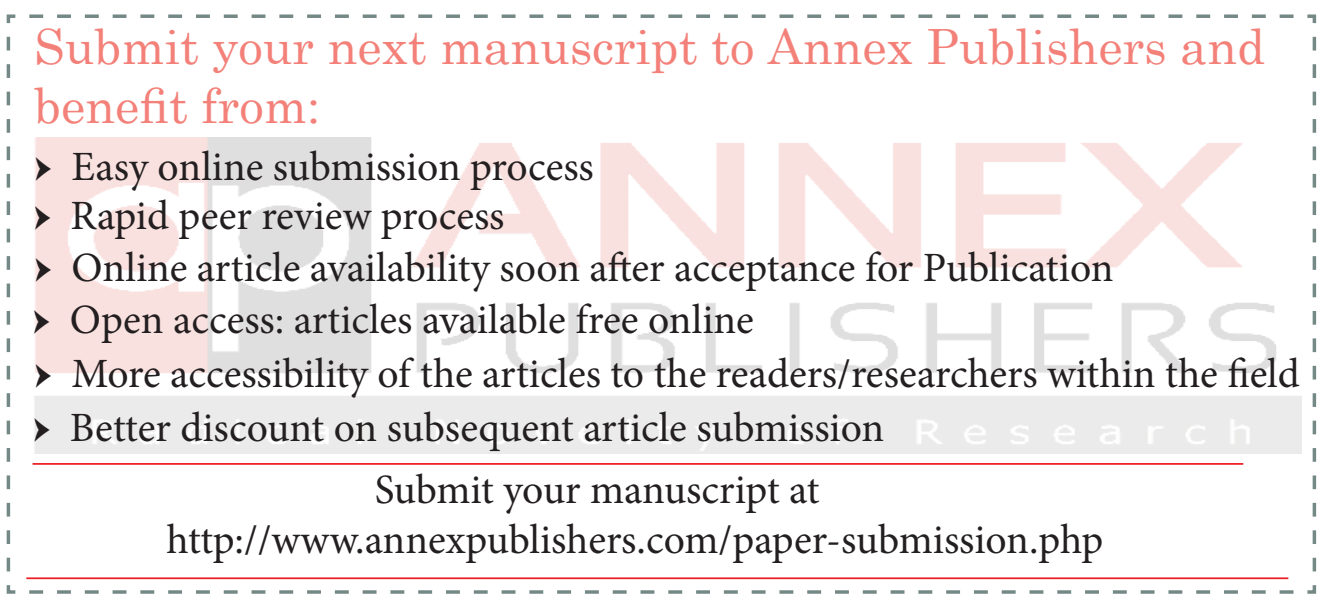

